\title{
A Dominant Position in Bussiness Partnership Agreement: How is Legalprotection for Less Dominant Entities?
}

\author{
Akadiyan Aliffia Husdanah ${ }^{1}$, M. Djafar Saidi ${ }^{2}$, Achmad Ruslan ${ }^{3}$ Aminuddin Ilmar ${ }^{4}$ \\ 1.2.3.4 Universitas Hasanuddin \\ Makassar, Indonesia \\ akadiyanaliffia@yahoo.co.id
}

\begin{abstract}
A dominant position is a situation where a business actor does not have a significant competitor in the relevant market in relation to the market share controlled, or the business actor has the highest position among his competitors in the relevant market in terms of financial capability, ability to access supply or sales, and ability to adjust supply between the demand for certain goods or services (Article 1 number 4 of Act Number 5 of 1999). The law also aims to provide legal certainty, so that it can encourage the acceleration of economic development in an effort to improve general welfare, as well as the implementation of the spirit and soul of the 1945 Constitution of the Republic of Indonesia. The form of abuse of dominant position by PT Forisa Nusapersada in the Pop Ice program The Real Ice Blender is PT. Forisa Nusapersada made IOM and an agreement with the owners of Beverage Kiosks and / or Market Stores not to sell competing products like Pop Ice has resulted in the loss or at least reduce the choice of consumers to get S'Cafe and Milkjus brand products in the market. Research Methodology using the statute approach method by examining the laws and regulations that relate to the legal issues being addressed. Departing from the unfair behavior of business actors above, given the characteristics and impact of the abuse of the dominant position referred to potential competitors and small business actors, The author is expected to better understand the existence of the abuse of a dominant position in a business competition.
\end{abstract}

Keywords- Business, Monopolistic, Competition.

\section{INTRODUCTION}

Development in the economic field must be aimed at the realization of social welfare based on Pancasila and the 1945 Constitution of the Republic of Indonesia which is based on economic democracy while taking into account the balance between the interests of business actors and the public interest. The principle of economic democracy requires equal opportunities for every citizen to participate in the process of production and marketing of goods and or services, in a healthy, effective and efficient business climate so as to encourage economic growth and the operation of a fair market economy. Therefore, every person who tries in Indonesia is required to be in a situation of fair and fair competition, so that there is no concentration of economic power on certain business actors, among others in the form of monopolistic practices and unfair business competition which is detrimental to society and is contrary to social justice.

Departing from such matter, then on March 5, 1999 the Government issued Law Number 5 of 1999 concerning Prohibition of Monopolistic Practices and Unfair Business Competition (hereinafter referred to as Law Number 5 of 1999) which was intended as a legal instrument to enforce the rule of law and provide equal protection for each business actor in an effort to create fair business competition. In addition, the Act also aims to provide legal certainty, so as to encourage accelerated economic development in an effort to improve public welfare, as well as the implementation of the spirit and spirit of the 1945 Constitution of the Republic of Indonesia.

The effective implementation of Law Number 5 of 1999 is expected to foster a healthy business culture so that it can continue to encourage and enhance competitiveness among business actors and can ensure market mechanisms work well and consumers enjoy the results of competitive processes or consumer surpluses. In fact, the goal of every rational business actor is to be able to develop their business as fully as possible or to be the best in their business. Ideally these goals will encourage every business actor to strive to improve their performance and competitiveness through innovation and efficiency so that they are superior to their competitors. If successful, the logical consequence is that the business actor will obtain a dominant position and or have significant market power in the relevant market. With this relative advantage, the business actor is able to dominate the relevant market or be able to maintain its strong position in the relevant market.

One example of alleged cases of unfair business competition practices related to the abuse of dominant positions in the strategic industry sector is that carried out by PT Forisa Nusapersada through the Pop Ice 
drink product The Real Ice Blender. Where is PT Forisa Nusapersada is the dominant business actor in the market for Processed Fruit Flavored Fruit Powder Beverage Products which has a market share of $90.09 \%$ to $94.3 \%$. Through these market forces, PT. Forisa Nusapersada has actually misused its dominant position by making agreements with the owners of Drinks Kiosks and / or Market Stores not to display and / or sell competing products. Such practices can certainly prevent or prevent consumers from obtaining Milkjuss and S'Cafe brand products while creating a barrier to entry to PT. Karniel Pacific Indonesia, which is a new business actor to enter and compete in a healthy market in the Processed Fruit Flavored Beverage Powder products.

\section{FINDING AND DISCUSSION}

Competition law is public law, therefore everyone who knows that a violation has occurred or is reasonably suspected to have occurred against Law no. 5 of 1999 or the party who is harmed as a result violation of this Law, may report in writing to the Commission about it. Market freedom in this system it is not uncommon to make the perpetrator performs the action (behavior) that make up the market structure which is monopolistic or oligopolistic. Formation market structure which monopolistic or oligopolistic is the embodiment of the condition unfair business competition. Monopoly is a component main thing that will make wealth concentrated in the hands of a few groups so that they can create social and economic disparities.

The definition of a dominant position legally can be seen in the provisions of Article 1 number 4 of Law Number 5 of 1999 which states a dominant position is a condition where a business actor does not have a significant competitor in the relevant market in relation to the market share controlled, or the business actor has the highest position among his competitors in the relevant market in terms of financial capability, ability to access supply or sales, and ability to adjust supply between the demand for certain goods or services."

Based on the provisions of Article 25 paragraph (2) of Law Number 5 Year 1999, business operators are considered to have a dominant position if one business actor or a group of business actors controls $50 \%$ (fifty percent) or more of the market share or certain types of goods or services and two or three business actors or groups of business actors control $75 \%$ (seventy-five percent) or more of the market share of certain types of goods or services. Therefore, it can be concluded that the dominant position is related to market domination of a certain type of goods and / or services in the relevant market by a particular business actor or group of business actors. Companies that have a dominant position have control over the markets in which they operate and have insignificant competitors or are generally referred to as small companies (fringe firms).

The dominant position can be held by one business actor or a group of business actors, or commonly known as monopoly, where the actor or business group controls the production and / or marketing of goods and / or for the use of certain services. The dominant position can also be controlled by two or more actors or groups of business actors that can be classified as oligopolies, namely the condition of a particular market where there are two or more business actors that have almost equal or balanced market power.

In essence, the position of the dominant business actor does not conflict with the laws and regulations, but rather encourages the business actor to be able to compete in the relevant market. The competition spurred businesses to carry out efficiency and innovation to produce quality products and competitive prices compared to selling prices from competitors. It is competition that drives business actors to become dominant business actors. On the other hand, dominant business actors are still considered to have the potential to abuse their position. In the horizontal direction, dominant business actors have the potential to build barriers for competitors / potential competitors (barriers) by implementing exclusionary strategies such as predatory pricing, tying, refusal to deal, and so forth. While in the vertical direction, dominant business actors have the ability to exploit suppliers or consumers, even not infrequently the dominant business actors carry out vertical integration, namely control of raw materials (upstream) to distribution / distribution (downstream).

Analysis of KPPU Decision Number 14 / KPPU-1 / 2015 in Case on Behalf of Reported Party of PT Forisa Nusapersada Based on the Application of Article 25 of Law Number 5 Year 1999 concerning Prohibition of Monopolistic Practices and Unfair Business Competition. The case began with a public report submitted to the KPPU Secretariat regarding allegations of unfair business competition practices by PT Forisa Nusapersada through the Pop Ice The Real Ice Blender program, with the following case position descriptions:

1) On December 29, 2014, PT Forisa issued Internal Office Memo No. 15 / IOM / MKT-DB / XII / 2014 concerning the Pop Ice The Real Ice Blender Program, which is addressed to Area Sales Promotion Manager (ASPM) and directed to the Area Sales Promotion Supervisor (ASPS).

2) IOM No. 15 / IOM / MKT-DB / XII / 2014 was published with the aim of maintaining the position of Pop Ice as a market leader and maintaining Pop Ice seller loyalty both at the 
market level and at the beverage stall level, by issuing the Pop Ice The Real Ice Blender Program.

3) Pop Ice The Real Ice Blender Program consists of three programs, namely the Drink Kiosk Exchange Assistance Program (BATU), the Drink Kiosk Display Program and the Market Shop Display Program.

4) To join the program, there are requirements that must be obeyed by beverage kiosks and market stores, namely not selling and not displaying (competing) products of competitors, which will later get a prize from PT Forisa Nusapersada if it meets these requirements.

5) Beverage Kiosks participating in the program sign a Pop Ice Display Contract Agreement which contains a regulatory clause willing to display Pop Ice products exclusively and not sell competitor products.

6) The action taken by PT Forisa Nusapersada has the potential to cause an unfair business competition in the milk powder beverage market throughout Indonesia.

7) Based on this, PT Forisa Nusapersada in the Pop Ice The Real Ice Blender Program is alleged to have violated Article 19 letter a; Article 19 letter b; Article 25 paragraph (1) letter a and Article 25 paragraph (1) letter c of Law Number 5 of 1999.

Related to unfair business competition cases conducted by PT Forisa Nusapersada in the Pop Ice The Real Ice Blender Program, an analysis can be carried out based on the examination procedures for the abuse of dominant position as stated in KPPU Regulation Number 6 Year 2010, namely defining related market. The definition of the relevant market is regulated in Article 1 number 10 of Law Number 5 of 1999. Guidelines for the application of the relevant market can refer to the provisions of KPPU Regulation Number 3 of 2009, where the relevant market can be divided into 2 (two):

1) Product relevant market, which is defined as competing products of certain products plus other products that can be substituted for these products. Other products become substitutes for a product if the existence of other products limits the space for price increases of these products. Thus the preferences or tastes of consumers are seen as a determining factor in defining the product market which is at least represented by the main indicators namely: price, character or characteristics of the product concerned and its usefulness (function).

2) Geographic relevant market, that is, areas where a business actor can increase prices without attracting new business actors or without losing significant consumers, who move to other business actors outside the region. Some determining factors in product availability are company policy, transportation costs, length of travel, tariffs and regulations that limit trade traffic between cities / regions. Based on these provisions is associated with cases of unfair business competition conducted by PT Forisa Nusapersada in the Pop Ice.

Based on the entire description as mentioned above, it can be seen that the Reported Party (PT Forisa Nusapersada) through the Pop Ice brand beverage product is the dominant business actor in the Dairy Beverage Fruit Powder Processed product market, because it has a market share exceeding $50 \%$ (fifty percent), which is $90.09 \%$ (ninety point zero nine percent) up to $94.3 \%$ (ninety four point three percent).

\section{IV.CONCLUSION}

A dominant position is a situation in which a business actor does not have a significant competitor in the relevant market in relation to the market share controlled, or the business actor has the highest position among his competitors in the relevant market in terms of financial capability, ability to access supply or sales, and ability to adjust supply between the demand for certain goods or services (Article 1 number 4 of Act Number 5 of 1999). The procedure for determining the existence of abuse of dominant position can be carried out by measuring the reach or scope of the relevant market, the existence of a dominant position in the relevant market and proving the behavior of abuse of dominant position. PT Forisa Nusapersada's form of abuse of dominant position in the Pop Ice The Real Ice Blender program is that PT Forisa Nusapersada made an IOM and an agreement with the Beverage Kiosk owner and / or Market Shop to not sell competing Pop Pop-like competitors' products has resulted in loss or at least whether or not it reduces the choice of consumers to get S'Cafe and Milkjus brand products in the market.

\section{REFERENCES}

[1] Ahmad Kaylani. 2011. Negara dan Pasar Dalam Bingkai Kebijakan Persaingan, Jakarta: Komisi Pengawas Persaingan Usaha.

[2] Andi Fahmi Lubis, et.al. 2009. Hukum Persaingan Usaha Antara Teks \& Konteks, Jakarta: Komisi Pengawas Persaingan Usaha dan Deutsche Gesellschaft für Technische Zusammenarbeit (GTZ) GmbH

[3] Ayu Sitoresmi. 2012. Strategi Brand Proliferationsebagai Bentuk Penyalahgunaan Posisi Dominan dalam Konteks Persaingan Usaha, 
Tesis, Fakultas Hukum Universitas Indonesia, Jakarta.

[4] Hikmahanto Juwana, et.al. 2003. Peran Lembaga Peradilan dalam Menangani Perkara Persaingan Usaha, Jakarta: Partnership for Business Competition (PBC).

[5] Kurnia Toha, Urgensi Amandemen UU tentang Persaingan Usaha di Indonesia: Problem dan Tantangan, Jurnal Hukum dan Pembangunan, Universitas Indonesia, 2019.

[6] Meita Fadhilah, Penegakan Hukum Persaingan Usaha Tidak Sehat oleh Komisi Pengawas Persaingan Usaha Dalam Kerangka Ekstrateritorial, Wawasan Yuridika, ejournal STHB, Bandung, 2019.

[7] M. Udin Silalahi, Perusahaan Saling Mematikan dan Bersekongkol: Bagaimana Cara Memenangkan?, Jakarta: Elex Media Komputindo, 2007.

[8] Mustafa Kamal Rokan. 2010. Hukum Persaingan Usaha, Jakarta, PT Raja Grafindo Persada.

[9] Susanti Adi Nugroho. 2001. Pengaturan Hukum Persaingan Usaha di Indonesia, Jakarta, Litbang MA.

[10] Y. Andri Zaimur. 2007. Prinsip-Prinsip Ekonomi Edisi Kedelapan Jilid 1, Jakarta: Erlangga.

[11]Law Number 5 of 1999 Concerning Monopolistic Practices and Unfair Business Competition.

[12]Rai Mantili, dkk, Problematika Penegakan Hukum Persaingan Usaha di Indonesia dalam Rangka Menciptakan Kepastian Hukum, Padjajaran Journal of Law, Universitas Padjajaran, Bandung, 2021.

[13]Regulation of the Business Competition Supervisory Commission Number 6 of 2010 concerning Implementation Guidelines for Article 25 concerning Misuse of Dominant Position based on Law Number 5 of 1999 concerning Prohibition of Monopolistic Practices and Unfair Business Competition.

[14]Academic Paper on Business Competition and Anti-Monopoly, Indonesian Supreme Court, 2005.

[15]Andi Saputra. 31 Agustus 2016. Promosi Tidak Sehat, Pop Ice Didenda Rp 11 Miliar, https://news.detik.com. 